\title{
Effect of Graded Levels of an Enhanced E.coli Phytase with Step-Wise Reduction of Supplemental Inorganic Phosphate on Growth Performance of Broilers Fed Corn-Soy Diet
}

-Author(s)

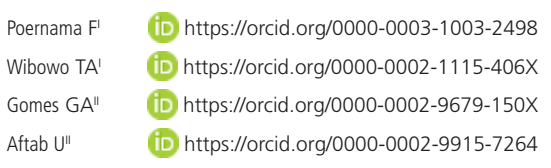

JAPFA Comfeed, Indonesia.

AB Vista, 3 Woodstock Court, Blenheim Road, Marlborough, Wiltshire SN8 4AN, UK.

\section{nMail Address}

Corresponding author e-mail address Usama Aftab

AB Vista Asia Pte Ltd, Singapore, Singapore 329682 - Singapore.

Phone: +65 90050526

Email: usama.aftab@abvista.com

\section{aKeywords}

Broiler, phytase, inorganic phosphate, phosphorus.

\section{ABSTRACT}

This study evaluated the potential of incremental doses of an enhanced Escherichia coli-derived phytase to support step-wise reduction of supplemental inorganic phosphate in an all-vegetable broiler diet. Corn-soybean meal-based diets containing 0.40/0.80\%, $0.35 / 0.70 \%$, and $0.30 / 0.60 \%$ avP and $\mathrm{Ca}$, respectively from $0-10$, 10-25, and 26-42 days posthatch served as experimental control (PC). Three test diets were formulated with 500, 1000, and 1500 FTU/kg of phytase assigned respectively an avP matrix of $0.15,0.19$, and $0.23 \%$ and a fixed $\mathrm{Ca}$ matrix of $0.15 \%$. An additional diet (PC++) containing extra avP and $\mathrm{Ca}(+0.05 \% \mathrm{avP} /+0.1 \% \mathrm{Ca})$ to that of $\mathrm{PC}$ was included to test if avP and Ca were not limiting in PC. Each diet was offered to 16 replicates of straight-run broilers kept in floor pens (30 birds per pen). $P C++$ had lower ( $p<0.05 ; 10$ and $25 d$ ) or similar (42 d) BW and toe ash compared with PC confirming the avP and Ca set in PC were sufficient to support optimal growth and bone mineralization. Compared to the PC, diets containing 1000 and 1500 FTU phytase had higher BW $(p<0.05)$ at 10 and $25 \mathrm{~d}$. For the overall period of $0-42$ $\mathrm{d}, \mathrm{Fl}, \mathrm{BW}$ and FCR did not differ across treatments. Percentage-, but not the absolute-, toe ash at phytase treated groups was significantly $(p<0.05)$ low compared with the PC. The experiment demonstrated that $1500 \mathrm{FTU} / \mathrm{kg}$ of enhance $E$. coli phytase supports optimal BW and FCR of broilers fed corn-soy diet largely void of supplemental inorganic phosphate.

\section{INTRODUCTION}

The effect of supplementary microbial phytase in improving the availability of phytate-bound phosphorus (PP) has been well documented in poultry and swine nutrition. Improved availability of PP in the diet by phytase allows reduction in the supplemental inorganic phosphates. This replacement value, often referred to as P-equivalency, typically follows a log-linear curve and is a function of the phytase in question (Augspurger et al., 2003; Dersjant-Li et al., 2015). The log-linear curves offer the flexibility to choose the most economical dosage under variable nutritional and price conditions. However, the maximum potential of phytases to replace inorganic phosphates and thus reduce feed costs is far from being completely exploited - e.g. a common approach is to use phytases to replace $0.10-0.15 \%$ AvP, despite the evidence that modern phytases can potentially offer more complete phytate destruction and much higher P-release than the former counterparts (Van der Klis \& Star, 2013; Walk et al., 2013; dos Santos et al., 2014; Zeller et al., 2015). Higher doses of phytase can potentially offer, 1) direct savings in the feed cost through replacing more of an expensive inorganic phosphate, and 2) improved technical performance associated with more complete 
phytate destruction (dos Santos et al., 2014; Gehring et al., 2013; Walk et al., 2014). In addition to the tangible commercial benefits, the use of higher doses of phytases helps reduce reliance on non-renewable inorganic phosphate reserves (Cordell 2016) and a further reduction in manure $\mathrm{P}$ (Kies et al., 2006).

The current experiment was designed to study the effect of incremental doses of an enhanced $E$. coli phytase on the growth performance and bone mineralization of broilers fed diets gradually reduced on avP and Ca. Our main objective was to test the hypothesis that a higher dose (1500 FTU per $\mathrm{kg}$ ) of an enhanced $E$. coli phytase should enable an allvegetable, corn-soy diet void of supplemental inorganic phosphate to be fed without negatively affecting the growth performance of broilers.

\section{MATERIALS AND METHODS}

Two thousand and four hundred $(2,400)$ newly hatched commercial straight-run broiler chicks (Lohman Indian River) were randomly allocated to 5 treatments, with 16 replicate pens per treatment, in a randomized complete block design using 30 chicks per experimental unit (floor pen). Table 1 presents a summary of the dietary treatments highlighting the phytase dose rates and also the inclusions of monocalcium phosphate by feeding phase. A corn-soybean meal-based diet with avP/Ca levels of $0.40 / 0.80 \%, 0.35 / 0.70 \%$, and $0.30 / 0.60 \%$, respectively for $0-10,10-25$, and $26-42$ days posthatch served as experimental control (PC); ingredient composition and calculated and analyzed nutrient content of PC are presented in Table 2. Three

Table 1 - Diet design and treatments.

\begin{tabular}{lcccc}
\hline Treatment & Added Phytase (FTU/kg) & Supplemental level of monocalcium phosphate, kg per metric ton of feed \\
\hline & & $1-10 d$ & $11-25 d$ & 11.4 \\
\hline$P C$ & None & 13.4 & 13.7 & 11.8 \\
$P C++$ & None & 15.7 & 4.3 & 2.4 \\
$-0.15 \% \mathrm{AvP} ;-0.15 \% \mathrm{Ca}^{\mathrm{A}}$ & 500 & 6.3 & 2.5 & - \\
$-0.19 \% \mathrm{AvP} ;-0.15 \% \mathrm{Ca}^{\mathrm{A}}$ & 1000 & 4.4 & - \\
$-0.23 \% \mathrm{AvP} ;-0.15 \% \mathrm{Ca}^{\mathrm{A}}$ & 1500 & 2.6 & - \\
\hline
\end{tabular}

Diets were formulated to contain $0.40,0.35$, and $0.30 \%$ avP, respectively for $0-10,11-25$, and $26-42 \mathrm{~d}$; the corresponding levels of total Ca were set to $0.80,0.70$, and $0.60 \%$ respectively.

A assumed avP and Ca matrix for corresponding dose of phytase.

Table 2 - Ingredient and nutrient composition of control (PC) diets.

\begin{tabular}{|c|c|c|c|}
\hline Ingredients & $1-10 d$ & $11-25 d$ & $26-42 d$ \\
\hline Corn & 59.4 & 62.5 & 68.1 \\
\hline Corn gluten meal & 3.2 & 3.9 & 5.9 \\
\hline Soybean meal & 31.1 & 26.4 & 19.4 \\
\hline Palm oil & 1.6 & 2.9 & 3.0 \\
\hline Limestone & 1.25 & 1.10 & 0.96 \\
\hline MDCP & 1.34 & 1.14 & 0.95 \\
\hline Salt & 0.30 & 0.27 & 0.19 \\
\hline Sodium bicarbonate & 0.34 & 0.28 & 0.28 \\
\hline L-lysine $\mathrm{HCl}$ & 0.31 & 0.31 & 0.29 \\
\hline DL-methionine & 0.32 & 0.28 & 0.16 \\
\hline L-threonine & 0.10 & 0.10 & 0.03 \\
\hline Choline Chloride & 0.06 & 0.06 & 0.07 \\
\hline Vitamin/Mineral mix & 0.30 & 0.30 & 0.30 \\
\hline Builders sand & 0.40 & 0.40 & 0.40 \\
\hline Total & 100 & 100 & 100 \\
\hline \multicolumn{4}{|c|}{ Calculations and analysis } \\
\hline AMEn, kcal per kg & 2950 & 3080 & 3175 \\
\hline$C P, \%$ & $22.1(22.1)$ & $20.5(20.4)$ & $18.6(19.4)$ \\
\hline Digestible lysine, \% & 1.24 & 1.12 & 0.94 \\
\hline Available P, \% & 0.40 & 0.35 & 0.30 \\
\hline $\mathrm{Ca}, \%$ & $0.80(0.74)$ & $0.70(0.66)$ & $0.60(0.61)$ \\
\hline Total P, \% & $0.67(0.66)$ & $0.61(0.58)$ & $0.54(0.54)$ \\
\hline Phytic P, \% & $0.24(0.26)$ & $0.23(0.25)$ & $0.23(0.25)$ \\
\hline $\mathrm{Na}, \%$ & $0.22(0.21)$ & $0.19(0.16)$ & $0.16(0.14)$ \\
\hline
\end{tabular}

*Analyzed nutrients in the parenthesis 
test diets were formulated with 500, 1000, and 1500 $\mathrm{FTU} / \mathrm{kg}$ of an Escherichia coli-derived phytase (AB Vista, Marlborough, UK) assigned respectively an avP matrix of $0.15,0.19$, and $0.23 \%$; the Ca matrix was set at $0.15 \%$ for all doses of phytases. An additional diet containing extra avP and $\mathrm{Ca}(+0.05 \%$ avP; $+0.1 \%$ Ca) to that of PC was included to make sure the PC was not deficient in avP and Ca. Test diets were steam-pelleted to $3 \mathrm{~mm}$ diameter with a conditioning temperature of $85^{\circ} \mathrm{C}$ and were offered ad-libitum as fine-crumbles (1-10 d), coarse-crumbles (11-25 d) or pellets (26-42 d).

Feed samples were analyzed for proximate constituents and total $\mathrm{P}$ and $\mathrm{Ca}$ were analyzed using induction coupled plasma method (AOAC 2005). Milled sample of test feeds were scanned using a FOSS NIR spectrophotometer for the prediction of phytate-P (Enzyme Services and Consultancy, UK). The phytase activity (Engelen et al., 1994; Engelen et al., 2001) in the test diets was analyzed in Enzyme Services and Consultancy, UK. Briefly, feed samples were extracted for $30 \mathrm{~min}$ in $25 \mathrm{mM}$ borate buffer at $\mathrm{pH} 10$ and analysis was conducted at $\mathrm{pH} 4.5$ and $60^{\circ} \mathrm{C}$ using sodium phytate as substrate. The phytase activity was based on the endpoint determination of phosphate using molybdovanadate color system. One phytase unit (FTU) is therefore defined as the amount of enzyme which liberates 1 micromole inorganic phosphorus per minute from sodium phytate at $\mathrm{pH}$ 5.50 and $37.0^{\circ} \mathrm{C}$ and under the specific conditions of the assay as described herein.

The experiment was conducted in a close-sided house with evaporative cooling system and concrete floor pens using rice hull as bedding material. Each pen measured $2.448 \mathrm{~m}^{2}$ and was equipped with a tabularself-feeder and tubular water drinkers. Feed and water were provided ad libitum. Birds were maintained under the lighting and management programs according to the supplier's management manual. The max/min temperature and relative humidity in the experimental house were $34.3 / 27.3^{\circ} \mathrm{C}$ and $57.5 \%$ during $0-7$ days of age, $30.6 / 26.0^{\circ} \mathrm{C}$ and $67.1 \%$ during $7-14$ days of age, $28.2 / 24.9^{\circ} \mathrm{C}$ and $72.5 \%$ during $14-28$ days of age and $28.1 / 25.1^{\circ} \mathrm{C}$ and $72.5 \%$ during $28-42$ days of age. All birds were vaccinated for Newcastle, Infectious Bronchitis, and Gumboro diseases at the hatchery.

Pen feed intake (FI) and body weight (BW) were recorded at the end of every feeding phase, and feed conversion ratio (FCR) corrected for mortality was calculated. At $25 \mathrm{~d}$ two birds (one male and one female) close to the pen average weight, from each pen were chosen for the measurement of toe ash. Body weight, feed intake, feed conversion ratio, livability, and toe ash were calculated and subjected to analysis of variance as a randomized complete block design using SPSS. Means were compared using Tukey's test using $p<0.05$ as conventional significance.

The study was conducted in Indonesia following the Law of the Republic of Indonesia No. 18, 2009 regarding the animal welfare and use in veterinary research

\section{RESULTS AND DISCUSSION}

The analyzed total $\mathrm{P}, \mathrm{Ca}$, and phytic $\mathrm{P}$ were in close agreement with the calculated values (Table 2). The phytase activity in starter and grower diets was close to the expected while the finisher diets showed lower than expected activity (Table 3 ). The average growth performance in this experiment was $3132 \mathrm{~g} \mathrm{BW}$ and $1.60 \mathrm{FCR}$ at $42 \mathrm{~d}$ which was marginally exceeding to the breed standard (Aviagen, 2014a).

Table 3 - Analyzed activity of phytase enzyme in test diets.

\begin{tabular}{|c|c|c|c|c|}
\hline Treatment & Expected Phytase (FTU/kg) & & Phytase & \\
\hline & & $1-10 d$ & $11-25 d$ & $26-42 d$ \\
\hline PC & None & $<L D$ & $<L D$ & $<L D$ \\
\hline $\mathrm{PC}++$ & None & $<\mathrm{LD}$ & $<\mathrm{LD}$ & $<\mathrm{LD}$ \\
\hline$-0.15 \%$ AvP; $-0.15 \% \mathrm{Ca}$ & 500 & 381 & 492 & 370 \\
\hline$-0.19 \%$ AvP; $-0.15 \%$ Ca & 1000 & 798 & 860 & 834 \\
\hline$-0.23 \%$ AvP; $-0.15 \% \mathrm{Ca}$ & 1500 & 1,150 & 1,200 & 1,080 \\
\hline
\end{tabular}

$<\mathrm{LD}=$ below limit of detection ( $<50 \mathrm{FTU} / \mathrm{kg}$ ).

Variability in the published estimates of the avP and Ca requirements of broilers (Yan et al., 2003; Yan et al., 2004; Fritts \& Waldroup 2006; Rousseau et al., 2012) makes it relevant to question the avP and $\mathrm{Ca}$ level in PC. It becomes more crucial in experiments aimed at establishing the 'mineral-sparing' effect of phytase since an over-formulation of avP in PC would likely lead to an erroneous overestimation of this effect. In view of this, we set avP and Ca level in our PC that was lower than those suggested by the major genetic suppliers as well as those practiced in the most commercial scenarios. In order to test if PC in our experiment was sufficient in 
avP and $\mathrm{Ca}$, an extra treatment $(\mathrm{PC}++)$ with additional avP and $\mathrm{Ca}(+0.05 \% \mathrm{AP} /+0.1 \% \mathrm{Ca}$ added to $\mathrm{PC})$ was included. Compared with the $\mathrm{PC}$, the treatment group with additional avP and $\mathrm{Ca}$ had lower $(p<0.05 ; 10$ and $25 \mathrm{~d}$ ) or similar (42 d) BW (Table 4) and toe ash (Table 5). Depressed growth performance at $\mathrm{PC}++$ appears to relate to reduced $\mathrm{Fl}$ mediated by higher $\mathrm{Ca}$ ( $\mathrm{PC}++$ had $0.1 \%$ higher $\mathrm{Ca}$ than $\mathrm{PC}$ ); similar effects of high dietary Ca have recently been reported in other studies using broiler (Ravindran, 2016) and pig (GonzálezVega, 2016) models. These data suggests that avP/ Ca level of $0.4 / 0.80,0.35 / 0.70$, and $0.30 / 0.60 \%$, as were set respectively for $1-10,11-25$, and 26-42 $d$ in our PC were sufficient to support the optimal growth performance and bone mineralization of broilers (Aftab \& Creswell, 2019).

Test diets were formulated with 500, 1000, and $1500 \mathrm{FTU} / \mathrm{kg}$ of phytase assigned respectively an avP/ Ca matrix of 0.15/0.15, 0.19/0.15, and 0.23/0.15. As a result of the increasing dosages of phytase, a stepwise reduction in the supplemental monocalcium phosphate (MCP) was seen until all added MCP was removed and hence no further reduction in the calculated avP was possible. As a consequence, the final two diets of the finisher series i.e. $-0.19 \%$ and $-0.23 \%$ AP were exactly the same except that the latter had higher phytase than the former (Table 1).

Compared to the PC, diets containing 1000 and 1500 FTU phytase had higher BW $(p<0.05)$ at 10 and $25 \mathrm{~d}$ (Tables 4). Improved BW at higher doses of phytase may be a result of the release of nutrients and provision of inositol associated with more complete phytate hydrolysis in the gut (Walk et al., 2014; Cowieson et al., 2011); this apparent advantage however did not continue through to the advance age and no across treatment differences were observed for $42 \mathrm{~d}$ BW and FCR. Percentage-, but not the absolute-, toe ash at phytase treated groups was significantly

Table 4 - Growth performance of broilers for 1-10, 1-25, and 1-42 d, posthatch.

\begin{tabular}{|c|c|c|c|c|c|}
\hline Treatment & Added phytase, FTU & Added MCP kg per MT* & Feed intake, $\mathrm{g}$ & Body weight, g & FCR \\
\hline & & & & $1-10 \mathrm{~d}$ & \\
\hline PC & 0 & 13.4 & $330^{a}$ & $330^{b}$ & 0.998 \\
\hline $\mathrm{PC}++$ & 0 & 15.7 & $317^{b}$ & $320^{c}$ & 0.990 \\
\hline$-0.15 \%$ avP & 500 & 6.3 & $337^{a}$ & $336^{\mathrm{ab}}$ & 1.004 \\
\hline$-0.19 \%$ avP & 1,000 & 4.4 & $340^{a}$ & $340^{\mathrm{a}}$ & 0.995 \\
\hline$-0.23 \%$ avP & 1,500 & 2.6 & $340^{a}$ & $340^{\mathrm{a}}$ & 0.999 \\
\hline Probability & & & $<0.001$ & $<0.001$ & 0.488 \\
\hline \multirow[t]{2}{*}{ Pooled SEM } & & & 2.75 & 2.39 & 0.006 \\
\hline & & & & $1-25 \mathrm{~d}$ & \\
\hline PC & 0 & $13.4 / 11.4$ & $1949^{a b}$ & $1468^{b}$ & $1.316^{\mathrm{b}}$ \\
\hline $\mathrm{PC}++$ & 0 & $15.7 / 13.7$ & $1913^{b}$ & $1441^{b}$ & $1.318^{b}$ \\
\hline$-0.15 \%$ avP & 500 & $6.3 / 4.3$ & $1951^{\mathrm{ab}}$ & $1469^{b}$ & $1.326^{\mathrm{b}}$ \\
\hline$-0.19 \%$ avP & 1000 & $4.4 / 2.5$ & $1981^{a}$ & $1505^{\mathrm{a}}$ & $1.277^{\mathrm{a}}$ \\
\hline$-0.23 \%$ avP & 1500 & $2.6 / 0$ & $1982^{a}$ & $1505^{a}$ & $1.312^{\mathrm{ab}}$ \\
\hline Probability & & & $<0.001$ & $<0.001$ & 0.003 \\
\hline \multirow[t]{2}{*}{ Pooled SEM } & & & 12.90 & 8.73 & 0.004 \\
\hline & & & & $-1-42 d_{-}$ & \\
\hline PC & 0 & $13.4 / 11.4 / 9.5$ & 5136 & 3142 & 1.591 \\
\hline$P C++$ & 0 & $15.7 / 13.7 / 11.8$ & 5003 & 3080 & 1.607 \\
\hline$-0.15 \%$ avP & 500 & $6.3 / 4.3 / 2.4$ & 5056 & 3094 & 1.605 \\
\hline$-0.19 \%$ avP & 1000 & $4.4 / 2.5 / 0$ & 5130 & 3182 & 1.601 \\
\hline$-0.23 \%$ avP & 1500 & $2.6 / 0 / 0$ & 5127 & 3164 & 1.601 \\
\hline Probability & & & 0.501 & 0.498 & 0.820 \\
\hline Pooled SEM & & & 47.56 & 64.25 & 0.01 \\
\hline
\end{tabular}

${ }_{\mathrm{a}-\mathrm{c} M e a n s}$ within the same column with no common superscript differ significantly $(p<0.05) ;{ }^{*} 1-10 \mathrm{~d} / 11-25 \mathrm{~d} / 26-42 \mathrm{~d}$.

$(p<0.05)$ low compared with the PC which was a result of numerically high weights of dried toes at all groups treated with phytase (Table 5).

The observation that $1500 \mathrm{FTU} / \mathrm{kg}$ of enhanced $E$. coli phytase supported optimal growth performance of broilers in the diets largely void of inorganic phosphates was in line with a previous study at our lab which using a high phytate, corn-soy-rice bran diet, demonstrated a complete substitution of supplemental inorganic phosphate in the grower (15-28 d) and finisher (2942 d) diets with 1500 FTU of phytase; the starting (0$14 \mathrm{~d}$ ) diet in this experiment had marginal $(1.2 \mathrm{~kg}$ per metric ton) added dicalcium phosphate (Aftab 2017). These findings corroborate the earlier mechanistic 
Table $\mathbf{5}$ - Dried toe weight, toe ash weigh and toe ash percentage of broilers at $25 \mathrm{~d}$.

\begin{tabular}{|c|c|c|c|c|c|}
\hline Treatment & Added phytase, FTU & Added MCP kg per metric ton* & Dried toe weight, $\mathrm{mg}$ & Toe ash weight, mg & Toe ash, \% \\
\hline PC & 0 & $13.4 / 11.4$ & 2657 & 345 & $13.03^{a}$ \\
\hline $\mathrm{PC}++$ & 0 & $15.7 / 13.7$ & 2782 & 351 & $12.62^{\mathrm{ab}}$ \\
\hline$-0.15 \%$ avP & 500 & $6.3 / 4.3$ & 2841 & 342 & $12.06^{b}$ \\
\hline$-0.19 \%$ avP & 1000 & $4.4 / 2.5$ & 2786 & 342 & $12.26^{b}$ \\
\hline$-0.23 \%$ avP & 1500 & $2.6 / 0$ & 2872 & 347 & $12.09^{b}$ \\
\hline Probability & & & 0.156 & 0.772 & 0.002 \\
\hline Pooled SEM & & & 50 & 4 & 0.13 \\
\hline
\end{tabular}

a-c Means within column with no common superscript differ significantly $(p<0.05)$

$1-10 \mathrm{~d} / 11-25 \mathrm{~d}$.

work showing a complete elimination of Inositol 6and 5-phosphate, coupled with a significant rise in the free-inositol in the gizzard content of young broiler chickens with 1500 FTU (Walk et al., 2014). Indeed, an extensive clearance of the higher phytic esters in the gastric phase is fundamental to the extent of phytate hydrolysis across the entire gastrointestinal tract (Walk et al., 2014; Troung et al., 2016). It is important to highlight, however, that several other nutritional factors influence in-vivo phytate hydrolysis and hence the optimization of these factors including e.g. dietary Ca (Tamim et al., 2004), avP, (Rodehutscord, 2016), and vitamin D3 (Mohammed et al., 1991) need to be considered in addition to the proper dose of phytase when target is to seek a complete elimination of supplemental inorganic phosphates in broiler diets.

In conclusion, the results of the current experiment demonstrated that increasing doses of phytase could help reduce significantly the reliance on inorganic phosphates. Our results showed that 1500 FTU/kg of enhance $E$. coli phytase supported optimal BW and FCR of broilers fed corn-soy diet largely void of supplemental inorganic phosphate i.e. $2.6 \mathrm{~kg}$ per metric ton for starter (1-10 d) diet with no added phosphate for grower (11-25d) or finisher (26-42 d) diets. This would have marked implications for sparing of non-renewable phosphate reserves and excretion of phosphorus in poultry manure.

\section{REFERENCES}

Aftab U. Towards an inorganic phosphate free nutrition for broilers. Asian Feed 2017;(dec.):30-31.

Aftab $U$, Creswell. Optimizing phosphorus in broiler diets. Asian Poultry 2019;(mar.):32-35.

AOAC - Association of Official Agricultural Chemists. Official methods of analysis. 18 $8^{\text {th }}$ ed. Gaithersburg; 2005.

Augspurger NR, Webel DM, Lei XG, Baker DH. Efficacy of an E. coli phytase expressed in yeast for releasing phytate-bound phosphorus in young chicks and pigs. Journal of Animal Science 2003;81:474-483.
Cordell D. Global phosphorus scarcity: a food secure future. Proceedings of $27^{\text {th }}$ Annual Australian Poultry Science Symposium; 2016 Feb. 14-17. Sydney (AUS): New South Wales; 2016. p.153-157.

Cowieson AJ, Wilcock P, Bedford MR. Super-dosing effect of phytase in poultry and other monogastrics. World's Poult. Sci. J. 2011; 67:225236.

Dersjant-Li Y, Awati A, Schulze H, Partridge G. Phytase in non-ruminant animal nutrition: a critical review on phytase activities in the gastrointestinal tract and influencing factors. Journal of the Science Food and Agriculture 2015;95:878-896.

Engelen AJ, Heeft FC van der, Randsdorp PHG, Smit ELC. Simple and rapid determination of phytase activity. Journal of AOAC International 1994;77:760-764

Engelen AJ, Heef FC van der, Randorp PHG, Somer WAC. Determination of phytase activity in feed by a colorimetric enzymatic method: Collaborative inter laboratory study. Journal of AOAC International 2001;84:629-633

Fritts CA, Waldroup PW. Modified feeding program for broilers based on commercial feeding intervals to sustain live performance and reduce total and water soluble phosphorus in litter. Journal of Applied Poultry Research 2006;15:207-218.

Gehring, CK, Bedford MR, Dozier III WA. Extra-phosphoric effects of phytase with or without xylanase in corn-soybean meal-based diets fed to broilers. Poultry Science 2013;92:979-991.

González-Vega JC, Stein H. Calcium transporters and gene expression and absorption of calcium in pigs. In: Walk CL, Kuhn I, Stein HH, Kidd MT, Rodehutscord M, editors. Phytate destruction - consequences for precision animal nutrition. Wagening: Academic Publisher, 2016.

Kies, AK, Kemme PA, Sebek LBJ, Piepen JM, Jongbloed AW. Effect of graded doses and a high dose of microbial phytase on the digestibility of various minerals in weaner pigs. Journal of Animal Science 2006;84:1169-1175.

Mohammed A, Gibney MJ, Taylor TG. The effects of dietary levels of inorganic phosphorus, calcium and cholecalciferol on the digestibility of phytate phosphorus by the chick. British Journal Nutrition 1991;66:251-259.

Ravindran V. Measurement of calcium digestibility in feed ingredients in poultry: methodology and challenges. In: Walk $\mathrm{CL}$, Kuhn I, Stein $\mathrm{HH}$, Kidd MT, Rodehutscord M, editors. Phytate destruction - consequences for precision animal nutrition. Wagening: Academic Publisher, 2016.

Rodehutscord, M. Interactions between minerals and phytate degradation in poultry - challenges for phosphorus digestibility assays. In: Walk CL, Kuhn I, Stein HH, Kidd MT, Rodehutscord M, editors. Phytate destruction - consequences for precision animal nutrition. Wagening: Academic Publisher, 2016 


\section{Corn-Soy Diet}

Rousseau, X, Lotourneau-Montmin MP, Meme N, Magnin M, Nys Y, Narcy A. Phosphorus utilization in finishing broiler chickens: effects of dietary calcium and microbial phytase. Poultry Science 2012; 91:2829-2837.

Santos TT, Walk CL, Srinongkot S. Influence of phytate level on broiler performance and the efficacy of two microbial phytase from 0 to 21 days of age. Journal of Applied Poultry Research 2014;23:181-187.

Tamim NM, Angel R, Christman M. Influence of dietary calcium and phytase on phytate phosphorus hydrolysis in broiler chickens. Poultry Science 2004;83:1358-1367

Truong HH, Yu S, Moss AF, Liu SY, Selle PH. Phytase degradation in gizzard is pivotal to phytase response in broiler chickens. Proceedings of $27^{\text {th }}$ Annual Australian Poultry Science Symposium; 2016 Feb. 14-17. Sydney (AUS): New South Wales; 2016. p.174-177.

Van der Klis JD, Star L. Efficacy of different phytase products in broilers. Proceedings of the 18th European Symposium Poultry Science; 2013; Çesme (TUR)

Walk CL, Wilkinson SJ, Bedford MR, Cowieson AJ. Influence of conditioning temperature on post-pellet efficacy of three microbial phytases for broilers from d 0 to 21. Proceedings of the 18th European Symposium Poultry Science; 2013; Çesme (TUR).
Walk. C, Santos TT, Bedford MR. Influence of superdoses of a novel microbial phytase on growth performance, tibia ash, and gizzard phytate and inositol in young broilers. Poultry Science 2014;93:1172-1177.

Yan F, Fritts CA, Waldroup PW. Evaluation of modified phosphorus levels with and without phytase supplementation on live performance and fecal phosphorus levels in broiler diets. 1. Full-term feeding recommendation. Journal Applied Poultry Research 2003;12:174-182.

Yan. F, Fritts CA, Waldroup PW. Evaluation of modified phosphorus levels with and without phytase supplementation on live performance and fecal phosphorus levels in broiler diets. 2. Modified early phosphorus levels. Journal Applied Poultry Research 2004;13:394-400.

Zeller, E, Schollenberger M, Kuhn I, Rodehutscord M. Hydrolysis of phytate and formation of inositol phosphate isomers without or with supplemental phytases in different segments of digestive tract of broilers. Journal of Nutritional Science 2015;4:1-12. 